\title{
PUBLIC SERVICE LAW: PRIVATIZATION'S UNEXPECTED OFFSPRING
}

\author{
TONY PROSSER*
}

I

\section{INTRODUCTION}

The United Kingdom was the pioneer, if not of privatization, of a large scale privatization program extending to the public utilities: And it remains in the forefront of attempts to introduce forms of the new public management using private sector techniques in public administration. ${ }^{1}$ One might think that this means that the role of public law, and of distinctive notions of public service embodied in law, have disappeared in those areas where privatization has taken place. Indeed, this perceived decline in public service law is the characteristic criticism of the British experience by commentators in Continental Europe. The Conservative governments of the United Kingdom certainly intended to replace hierarchical administrative controls with a marketplace in which resort to the courts on public law matters would be unnecessary. ${ }^{2}$

In this article, however, I hope to suggest a paradox. The United Kingdom has experienced a new growth of public service law in relation to the privatized utilities. This has resulted in a convergence of the tradition of the United Kingdom and that of nations such as France and Italy, where public service has played a central role in public law, due in part to a unique rhetoric of public service in the Continental tradition. Indeed, it could be argued that the regulatory reform that accompanied privatization has made possible the development of a distinct discipline of public service law in the United Kingdom. ${ }^{3}$ In this article, I define public service law as law designed to make basic public services

Copyright $@ 2001$ by Tony Prosser

This article is also available at http://www.law.duke.edu/journals/63LCPProsser.

* John Millar Professor of Law, The University of Glasgow, Scotland, U.K.

1. For examples of the massive literature on this subject, see M.E. BEESLEY, PRIVATIZATION, Regulation AND Deregulation (2d ed. 1997); COSMO Graham \& TONy Prosser, PRIVATIZING PUBliC ENTERPRISES (1991); Michael J. Goldsmith \& Edward C. Page, Farewell to the British State?, in PUBLIC SECTOR REFORM 147 (Jan-Erik Lane ed., 1997).

2. For an insider's view, see C.D. Foster, Privatization, Public OWNership AND THE REGULATION OF NATURAL MONOPOLY 258-420 (1992).

3. For further discussion of public service law, see PUblic SERVICES AND CITIZENSHIP IN EUROPEAN UNION LAW (Mark Freedland \& Silvana Sciarra eds., 1998); H.W. MacLauchlan, Public Service Law and the New Public Management, in THE PROVINCE OF ADMINISTRATIVE LAW (Michael Taggart ed., 1997). The Continental literature is, of course, enormous. See, e.g., CONSEIL D'ETAT, ÉTUDES ET DOCUMENTS No. 46, RAPPORT PUblic 1994 (1995); RENAUd DENOIX DE SAINT MARC, LE SERVICE PUBLIC (1996). 
available to all citizens without discrimination. This may require modification of the operation of markets and recognition of the need to compensate for substantive inequalities by providing services to the disadvantaged. Thus, public service law has both a descriptive and a normative dimension. It is descriptive in that it is concerned with goods and services provided by institutions between the market and the state, which may include public enterprises at arm's length from government. It is normative in the sense that it is based on egalitarian rights derived from citizenship rather than an ability to bid in the marketplace. ${ }^{4}$ My discussion of the development of a discipline of public service law in the United Kingdom will be limited to the privatization of public utilities.

II

\section{The Absence of A Tradition of PUblic SERVICE IN THE United KINGDOM}

In marked contrast with their Continental neighbors, the British have traditionally been reluctant to enshrine requirements of public service in their system of law. During the nineteenth century, however, a relatively little-known body of common law developed to ensure access to monopoly services and to avoid discrimination in the way in which such access was provided. ${ }^{5}$ The bestknown of these cases concerned access to a dock monopoly, ${ }^{6}$ but other examples included rights of access to ferries, bridges, and other early public utilities.' These cases may represent an early attempt to develop competition law in the interest of economic efficiency by minimizing market distortions created by monopoly power. Implications of this trend in the case law reached beyond competition law, however. And as Paul Craig has documented, the cases suggest the recognition of some form of public property rights triggered by the possibility of restrictions on public access to essential, but privately owned, services. $^{8}$

These cases could have supported the establishment of principles concerned with rights of equal access to public services, like those that developed in France that are described below. Indeed, in the United States, cases such as Allnutt $v$. Inglis were influential in forming a basis for the constitutional acceptance of utility regulation. ${ }^{9}$ In the United Kingdom, however, they were largely forgotten, especially after the nationalization of the public utilities, culminating in the statutes of the Labour Government in the late 1940s. Certain nationalization statutes included a number of provisions to protect users, such as the stat-

4. For a similar conception, see Mark Freedland, Law, Public Services and Citizenship -New Domains, New Regimes, in PUBliC SERVICES AND CITIZENSHIP IN EUROPEAN LAw, supra note 3, at 1.

5. See Paul P. Craig, Constitutions, Property and Regulation, 1991 PuB. L. 538.

6. See Allnutt v. Inglis, 104 Eng. Rep. 206 (K.B. 1810).

7. See Magistrates of Kircaldy v. Greig, 8 D. 1247 (Scot. 1846).

8. See Craig, supra note 5, at 542 .

9. The seminal case is Munn v. Illinois, 94 U.S. 113 (1876). For a more detailed account, see Craig, supra note 5, at 543-51. 
utes that required supply to be made available according to demand, and prohibited undue discrimination against particular types of users. ${ }^{10}$ These statutes thus reflected the concerns of the nineteenth-century cases. However, these provisions did not constitute any coherent pattern of consumer protection. Furthermore, they were vague and difficult to interpret, and could not form the basis for a corpus of public service law. ${ }^{11}$ Instead, the citizen's recourse against decisions of the public utilities was to be political rather than legal. ${ }^{12}$ This approach proved to be remarkably ineffective, and was certainly incapable of resisting attempts to make the nationalized industries behave like ordinary capitalist businesses in the later days of nationalization. ${ }^{13}$ The nationalized industries became notorious for poor customer relations, notably the ineffectiveness of arrangements to protect vulnerable families from disconnection of essential services. $^{14}$ There was one major achievement under nationalization: the creation of an infrastructure to provide what is now termed "universal service" throughout the United Kingdom. There was no parallel development of legal doctrines of public service, however, such as those that emerged in France. Technological advances were seemingly not reflected in new legal conceptions of citizenship.

At the time of privatization, British policymakers certainly had no intention of embodying principles of public service in law; indeed, the British Government was determined to avoid legal controls as much as possible. ${ }^{15}$ Some perceived law as a way to facilitate meddling by courts, as well to create an unnecessary recourse to legal rights where market solutions would be more appropriate. ${ }^{16}$ It would be a serious mistake to view the privatization process as having ended the relevance of public service to the utilities, however. Somewhat reluctantly, the British Government established new regulators for each utility sector, initially with the aim of restraining monopoly until it could be replaced by competition. ${ }^{17}$ Nevertheless, political compromises had to be made, and the legislation setting out the duties of ministers and of the new regulators in relation to the public utilities contained a number of different duties mixing economic and social rationales. ${ }^{18}$ For example, in all cases, meeting all reason-

10. See, e.g., T. Sharpe, Undue Price Discrimination and Undue Preference: A Legal Perspective, 2 CONSUMER POL'Y REV. 33 (1992).

11. See Terence Daintith, The United Kingdom, in Public And PrIVATE ENTERPRISE IN MiXed ECONOMIES (Wolfgang Friedmann ed., 1974). For the flexibility of the duties in practice, see South of Scotland Electricity Board v. British Oxygen Co., 3 All E.R. 199 (1956).

12. For an overview of the problems, see TONY PROSSER AND PUBLIC CONTROL 194-221 (1986).

13. See id. at 36-74.

14. See id.; see also NATIONAL ECON. Dev. OfFice, A Study of UK NATiOnalised INDUSTRIES (1976).

15. The seminal statement of this view of regulation is contained in the report commissioned from an academic who later became a regulator of the electricity industry; that report formed the basis for the price control system adopted for each utility. See STEPHEN LitTlechiLd, REgulation of BRITISH TELECOMMUNICATIONS PROFITABILITY (1984); FOSTER, supra note 2.

16. See generally LITTLECHILD, supra note 15.

17. See id.

18. See generally TONy PRosser, LAW AND THE REgulators 5-24 (1997). 
able consumer demands forms part of the legislative requirements, reflecting a duty to provide a form of universal service. ${ }^{19}$ Legislators retained prohibitions on undue preference or undue discrimination from the nationalization statutes, and they included special duties requiring ministers and regulators to pay special regard to the interests of consumers, especially those in rural areas, pensioners, and the disabled. ${ }^{20}$ These by no means formed a general or consistent body of public service law in themselves, but are nevertheless important in suggesting that the utilities are different from other enterprises and that requirements based on social solidarity-to use the Continental phrase-are not irrelevant even after privatization. These duties are now partially replaced by a new duty in the Utilities Act 2000, which will be discussed in more detail after a description of the establishment and practice of the regulatory authorities.

III

\section{THE INSTITUTION OF REGULATORY AgENCIES AND SOCIAL REGULATION IN PRACTICE}

New independent regulatory authorities were thus established for each of the privatized utilities (telecommunications, water, rail, gas, and electricity). ${ }^{21}$ The British system, unlike others, vests legal powers for each sector directly in Directors-General rather than in commissions, though they are assisted by regulatory offices. The regulatory offices are the Office of Telecommunications, the Office of Water Services, the Office of the Rail Regulator. the Office of Gas Supply, and the Office of Electricity Regulation; the latter have merged into the Office of Gas and Electricity Markets, shortly to be renamed the Gas and Electricity Markets Authority. ${ }^{22}$ Originally, these offices were to have limited importance, which would wither away with the growth of competition. Instead, the regulators have now become a permanent and influential presence. ${ }^{23}$ The regulators' main tasks have been to reset price controls for monopoly areas of utility operation, and increasingly to act as specialist competition authorities for those areas in which competition has been introduced, notably in telecommunications and the supply of gas and electricity. This latter role increased in importance in March 2000, when the regulators acquired the power to implement the reformed U.K. competition law in their respective sectors. ${ }^{24}$

19. See Telecommunications Act, 1984 , § 3(1)(a) (U.K.); Gas Act, 1986, § 4(1)(a) (U.K.); Electricity Act, 1989, § 3(1)(a) (U.K.); Water Industry Act, 1991, § 2(3)(a) (U.K.); Railways Act, 1993, § 4(1)(b) (U.K.).

20. See, e.g., Telecommunications Act, 1984, §§ 3(1)(a), 3(2)(a) (U.K.).

21. Those for gas and electricity have now been merged, and one regulatory authority has been added for the postal service. For details of the original authorities, see PROSSER, supra note 18. The arrangements for the postal service were announced in DEPARTMENT OF TRADE AND INDUS., POST OfFICE Reform: A World Class SERVICE For THE 21st CENTURY, 1999, Cmnd. 4340 and are implemented by the Postal Services Act, 2000, §§ 1-5 (U.K.).

22. See Utilities Act, 2000, $\S \S 1-8$ (U.K.).

23. For the view of the regulators as essentially temporary controls on remaining areas of monopoly, see generally LITTLECHILD, supra note 15.

24. See Competition Act, $1998, \S 54$, \& sched. 10 (U.K.). 
The regulators, however, have also treated some types of social regulation designed to protect consumers as within their power. All regulatory agencies have established service standards, which encompass general quality of service indicators as well as provide rights of compensation for individual consumers. ${ }^{25}$ Certain utilities have encountered particularized social regulatory developments. In telecommunications, for example, one of the fears at the time of privatization was that the number of public phone booths would be drastically reduced, especially in rural and low-income areas. To avoid this, complex provisions were included in British Telecom's license restricting the circumstances in which such phone booths could be closed. ${ }^{26}$ The regulator also mounted a major campaign to ensure that the phones actually worked. Competition has been permitted also in the provision of public phone booth services. As a result of these developments, the number of phone booths increased considerably, from under 80,000 in 1987 to about 140,000 now, although a decline in their profitability due to the growth of mobile telephony is likely to lead to price increases. ${ }^{27}$

The second area of regulation with a strong social dimension is that of special tariffs for low users. A low-user tariff emerged from discussions between British Telecom and the regulator leading to the review of the Company's regulated tariffs in $1989 .^{28}$ Proponents of the tariff justified it as maximizing the value of the telephone network as a national resource by permitting as many people as possible to be connected to it. ${ }^{29}$ Later versions of the scheme, however, were targeted more closely toward those who could not afford to pay. ${ }^{30}$ During the mid-1990s, a major review of universal service in telecommunications was carried out, inspired partially by the emergence of universal service concerns at a European level. ${ }^{31}$ The consultative paper produced by the British regulator stressed the fundamental role that telecommunications services play in society and that this role requires that all people, whatever their income or geographical location, must have access to basic telecommunications facilities. ${ }^{32}$ Following the universal service review, a new tariff was introduced to provide a limited service at very low cost, and steps were taken to reduce the level of disconnections for non-payment by fifty percent. ${ }^{33}$ A further review of universal

25. See the Competition and Service (Utilities) Act, 1992 (U.K.).

26. See Office of Telecommunications, A Better Deal For Payphone Users (1998) (visited Nov. 16, 2000) <http://www.oftel.gov.uk/consumer/payp298.htm>.

27. See id.

28. See OfFice of Telecommunications, Universal Telecommunications Services: Proposed ARrANGEMENTS For UNIVERSAL SERVICE IN THE UK FROM 1997 (1997) (visited Nov. 16, 2000) <http://www.oftel.gov.uk/consumer/uniserv2/chap1.htm>.

29. See id.

30. See id.

31. See id.

32. See OfFice of Telecommunications, Universal Telecommunications Services (1999) (visited Nov. 16, 2000) <http://www.oftel.gov.uk/consumer/uts799.htm>.

33. See id. 
service was initiated in 1999. ${ }^{34}$ Perhaps the most interesting question raised by this review is how universal service will develop in the new world of media convergence. The universal service review had included the provision of enhanced services for schools and public libraries, but this was pursued separately with the establishment of a task force to assess the needs of such institutions and to propose a voluntary scheme for such access. Such a scheme is now being implemented by the industry and the government with advice from the regulator. ${ }^{35}$ However, the 1999 consultation on universal service includes the issue of whether universal service principles should be extended beyond basic voice telephony to include the provision of higher bandwidth to permit fast access to Internet and other advanced services.

In the gas and electricity industries, the major social concern has been the disconnection of supply. In gas, disconnection for failure to pay had been used widely before privatization; however, disconnections rose immediately after privatization from 35,626 to 60,778 in $1987 .^{36}$ Two years later, the regulator announced a modification of British Gas's license introducing new procedures aimed at limiting disconnections. ${ }^{37}$ The new provisions effectively prevented disconnection unless the customer had first been offered a pre-payment meter as an alternative. The meter allows payment by pre-paid token before consumption and can be set so as to recover debt. The effect was to reduce disconnections radically, with a drop to under 20,000 by 1990 and again to 14,000 in 1995 , although by 1998 , they had risen again to almost $30,000 .^{38}$

Similarly, in electricity disconnections were running at the rate of 70,000 per annum before privatization. Provisions in the Electricity Act of 1989 and in the licenses issued to electricity companies prevented disconnection where there is a serious dispute, and required the issue of a code of practice that largely precluded disconnection unless a prepayment meter had been offered as an alternative. As a result, disconnections dropped dramatically to below 20,000 in the year after privatization, and by 1995-96, only 674 domestic customers were disconnected for non-payment of bills, with a further fall to around 400 in $1998 .^{39}$ Despite the recent price increase for gas, this decline in disconnections has proceeded at a remarkable rate, even if a couple of qualifications must be noted. First, developments in metering technology played an important part in the decline; and second, the figures hide the extent of "self-disconnection" through inability to pay with a prepayment meter. ${ }^{40}$ Further discussion on recent developments to limit the effects of fuel poverty is given below.

34. See id.

35. See id.

36. See Office of Gas and Electricity Markets, Social Action Plan: Discussion

PAPER (May 1999) (visited Nov. 17, 2000) <http://www.ofgem.gov.uk/docs/socialac.pdf>.

37. See id.

38. See id.

39. See id.

40. For more information on these issues, see OFFICE OF GAS AND ELECTRICITY MARKETS, SOCIAL ACTION PLAN, supra note 36. 
Because the supply of gas and electricity is now competitive, a large number of new suppliers have entered the market. There were considerable fears about the effect of these developments on social obligations. The first concern related to the practice of "cream skimming." By definition, opening up the market signalled an end to universal tariffs (which never fully applied to the energy market in the United Kingdom anyway). The fear was that new entrants would offer service only to the most profitable customers, assumed to be the larger consumers, leaving the poor as an unprofitable remainder retained by the former monopoly supplier. Second, it was feared that the social obligations applying to the monopoly supplier would not apply to competitors.

In gas, a number of strategies have been employed to avoid these problems. All competing operators have to be licensed, and legislation forbids the granting of a license that is framed in such a way as to exclude premises likely to be occupied by persons who are chronically sick, disabled, of pensionable age, or who are likely to default in the payment of charges. ${ }^{41}$ This prevents a new supplier from excluding poor inner-city areas from supply, for example. Licenses require that all domestic customers in the license area be supplied with gas without undue preference or undue discrimination in the processing of applications, thus retaining a type of universal service requirement. ${ }^{42}$ A dominant supplier also is prohibited from undue preference or undue discrimination in charges: Price caps will continue to apply to the key British Gas tariffs, including the tariff for supply by pre-payment meter, until April 2001 when the market is expected to be fully competitive. ${ }^{43}$ All social requirements in the licenses, such as the disconnection procedures and special obligations toward old or disabled persons, apply to all suppliers, not just to the former monopolist. So far, these provisions have been successful in avoiding the worst of the predicted problems. There is evidence that new suppliers are offering deals for all types of consumers, not just the most profitable ones; however, the lack of innovative arrangements for savings and for greater reductions in tariffs for prepayment meter customers has been criticised. ${ }^{44}$ Provision was also made for a levy on gas suppliers should any particular supplier be forced to bear an unfair share of the burden of uneconomic customers; however, this provision has never been used. ${ }^{45}$ Similar provisions have been introduced for the competitive electricity market,

41. See Gas Act, 1986, § 7A(8)(b) (U.K.), as amended by Gas Act, 1995 (U.K.).

42. See Department of TRAde And Indus., GaS ACT 1995: Determination of the STANDARD CONDITIONS OF GAS SUPPLIERS' LICENSES cond. 2(3) (1996).

43. OfFice of Gas and Electricity Markets, Review of British Gas Trading's Price REgulation: FinAl PROPOSAls (Feb. 2000) (visited Nov. 29, 2000) <http://www.ofgem.gov.uk/docs/ pcfeb.pdf $>$.

44. See National Audit Office, Giving Customers A Choice: The Introduction Of COMPETITION INTO THE DOMESTIC GAS MARKET, HC 403, 1998-99.

45. See DEPARTMENT OF TRADE AND INDUS., supra note 42, cond. 6. 
and price controls are being retained until 2002, although here, there is no provision for a levy to support high social costs. ${ }^{46}$ Finally, the Utilities Act 2000 contains new powers permitting the Secretary of State to adjust charges for electricity and gas to help disadvantaged groups of customers, and these powers permit the provision of cross-subsidy in their favour, although this is to be used only as a last resort. ${ }^{47}$

The story in water and sewerage is in many ways similar, although there has been no discussion of the introduction of a competitive domestic market. Controversy has centered mainly around the issue of disconnections. The health implications of living without a water supply are, of course, particularly severe, not just for the disconnected consumer, but for other households that can be affected by disease. Again, there was a substantial rise in the number of disconnections after privatization; by 1991-92 more than 21,000 households were disconnected each year. ${ }^{48}$ In 1992, the regulator issued guidelines to the companies requiring improved procedures before disconnection took place. ${ }^{49}$ These procedures resulted in a gradual but substantial drop in the number of disconnections to 10,000 in $1994-95^{50}$ The introduction of prepayment meters as an alternative is more difficult to implement for water utilities, although a number of companies did employ budget payment units that allow use of a card for advance payment, followed by an emergency credit period of a week. ${ }^{51}$ However, a court ruled that these budget payment units were unlawful because they amounted to disconnection without the statutory protections required by the legislation and licenses. $^{52}$ The legislature has recently passed the Water Industry Act of 1999, which prohibits disconnection of water and sewerage services from residences for non-payment of charges and also prohibits the use of budget payment units. The Act also requires charging schemes to be approved by the Director General of Water Services in accordance with regulations issued by the Secretary of State. ${ }^{53}$ The regulations enable those in vulnerable groups such as those with three or more dependent children or suffering from specified medical conditions to pay an average charge rather than that based on their metered consumption. $^{54}$

46. For similar criticisms of the extent of benefits for disadvantaged consumers in the electricity market, see NATiOnal Elec. Consumers Council, Assisting DisAdvantaged Consumers: PRACTICAL PROPOSALS (1999).

47. See Utilities Act, 2000, $§ \S 69,98$ (U.K.)

48. See John ERnst, WhOSE UtILITY? The Social IMPACT OF PUblic Utility PRIVATIZATION AND REGULATION IN BRITAIN 149 (1994).

49. See OfFice of WATER SERV., Guidelines On DEbT AND DisCONNECTION (1992).

50. See Alicia Herbert \& Elaine Kempson, WAter DebT And Disconnection 6 (1995).

51. See id. at 69-73.

52. See R v. Director General of Water Services ex parte Oldham MBC, 31 H.L.R. 224 (1998), Case Note, R v. Director General of Water Services ex p. Oldham MBC, 9 UTIL. L. REV. 123 (1998).

53. See Water Industry Act, 1999, §§ 1-5 (U.K.).

54. The Water Industry (Charges) (Vulnerable Groups) Regulations, S.I. 1999, No. 3441, as amended by the Water Industry (Charges)(Vulnerable Groups)(Amendment) Regulations, S.I. 2000, No. 519. 
The protection of universal service in the case of railroads has taken a different path. For some time, even before privatization, the government had made separate payments to protect socially necessary but economically inefficient lines. ${ }^{55}$ This practice continues today in the form of franchise payments made to the companies operating rail services. ${ }^{56}$ Detailed provisions limit service closures and protect a minimum level of service. ${ }^{57}$ Historically, the procedures governing passenger service closures have been under public control, and in the past, closure hearings have been prolonged and controversial. ${ }^{58}$ When there are objections to a proposed station or line closure, a regional committee must hold a hearing to investigate whether the closure will cause hardship. The committee reports its findings to the regulator, who then determines whether the closure will cause hardship and decides whether it will take effect. ${ }^{59}$ The decision may be appealed to the minister, although the Transport Bill before the Parliament at the time of writing proposes that the decision be that of the minister rather than that of the regulator in all cases. ${ }^{60}$ No rail closures of any importance have taken place since privatization, because of their political unpopularity, although the future position of rail closures after franchises have been renewed is less certain. ${ }^{61}$ The franchise agreements also incorporate minimum service requirements on lines protecting potentially unprofitable services such as late evening trains. ${ }^{62}$

I do not wish to suggest that these somewhat particularistic attempts to prevent the exploitation of more vulnerable consumers are necessarily satisfactory. As mentioned above, in the competitive energy markets, a number of sources have expressed concern that, although poor families have gained, they have gained less than the more prosperous. ${ }^{63}$ The major change in this area, however, is from consumer protection depending on the goodwill of an industry (or on very ineffective political mechanisms) to rules enforceable by regulators, normally taking the form of license conditions under which enterprises operate or codes of practice required by license conditions. Indeed, under public ownership, the interests of government and the enterprise could often coincide at the expense of the consumer. For example, raising energy prices and requiring the proceeds to be paid to the government through repayment of debt or as a direct levy may be used as a form of highly regressive surrogate taxation without the

\footnotetext{
55. See Transport Act, 1968, $\S 38-40$ (U.K.).

56. See Railways Act, 1993, §§ 23-31 (U.K.).

57. See id. $\$ \S 37-50$.

58. See, e.g., PROSSER, supra note 12 , at 165-68.

59. See Railways Act, 1993, § 43 (U.K.).

60. See id. $\S 44$.

61. For a decision by the courts preventing evasion of these procedures, see Highland Regional Council v. British Railways Board, 1996 SLT 274 (1st Div.).

62. For a successful challenge to the first version of the requirements, see $R v$. Director of Passenger Rail Franchising, ex parte Save Our Railways, TIMES (London), Dec. 18, 1995 (C.A.).

63. See, e.g., NATIONAL ElEC. CONSUMERS COUNCIL, supra note 46.
} 
inconvenience of passing legislation. ${ }^{64}$ Although at the time of privatization there was a similar identity of interests between the government (which wanted to sell shares successfully) and industries (which wanted to be privatized on favourable terms in the later operation of the regulated utilities), the role of the regulators has brought questions about the best arrangements for protecting disadvantaged consumers far more into the open. Indeed, privatization has removed the direct incentive of government as owner to maximize industry returns. The creation of a network of independent regulators has brought to the forefront the question of how extensively constraints should be imposed on profit-maximization by utility enterprises. These constraints have been imposed by law, normally in the form of provisions in the licenses of the utility enterprises, rather than by informal and secretive intervention. The creation of independent regulators was originally viewed as a way of increasing investor confidence by preventing arbitrary intervention by governments after privatization. Paradoxically, however, it has formed the most important basis for the creation of an emerging body of public service law.

IV

\section{REGULATORY AGENCIES AND REGULATORY REFORM}

Two conclusions should be apparent from the description of the process of privatization in the United Kingdom. First, the utility regulators have not limited themselves to economic regulation; at times, they act for social reasons. Second, there is no coherent pattern to this; the interventions have been somewhat pragmatic and have differed from utility to utility. One problem hampering their efforts has been the concern that social interventions by regulators are undemocratic. Some argue that the regulator should be restricted to applying economic criteria with the aim of maximizing efficiency. Social goals, by contrast, should be left to government which, unlike the regulators, has a democratic mandate..$^{65}$ This view was shared to a degree by some of the utility regulators. For example, the former Director of Gas Supply refused to support energy-saving measures by levying a charge on consumers because she considered that to be a matter for the government and for Parliament to decide. ${ }^{66}$ Currently, however, measures are under consideration to create a clearer division of responsibilities through the current process of regulatory reform.

The Labour Government elected in 1997 has been more sympathetic to the potential need for social regulation than its predecessors: "Ensuring that the services provided by [the utilities] are available to all members of society, including the most vulnerable, on fair terms, is important to the Government's

64. For additional examples of this, see Prosser, NATIONALIZED INDUSTRIES supra note 12, at 63-69.

65. See FOSTER, supra note 2, at 316-23.

66. See PROSSER, supra note 18 , at 110-13. 
wider objective of creating a fairer society." ${ }^{67}$ The question of how to create a more orderly set of arrangements for public access to utilities was a central aim of the review of utility regulation carried out in 1998 which resulted in the Utilities Act $2000{ }^{68}$ The review concluded that "the Government, not regulators, should determine the social objectives of regulation," and proposed a new approach under which the government will issue statutory guidance to regulators in each sector. ${ }^{6}$ However, where new measures with significant financial implications are to be imposed, new primary legislation will be passed, rather than using regulatory guidance. For example, regarding the controversial question of energy efficiency levies on consumers, the government has stated that new standards of performance to deliver energy and carbon savings through the establishment of energy saving schemes funded by a levy "would fall into the category of measures which should be implemented through new specific legal provision rather than relying on guidance to the regulator." 70 The new Act indeed includes specific powers to set efficiency standards by government. ${ }^{71}$

In one respect the Utilities Act 2000 has been a major disappointment in that during Parliamentary proceedings, the government decided to limit its applicability to the energy utilities (electricity and gas); telecommunications and water will thus wait for possible reform of regulation some time in the future. ${ }^{72}$ Nevertheless, some important changes relating to social regulation have been included. Thus the energy regulator will have a duty to heed guidance issued by the minister on social and environmental matters. ${ }^{73}$

Existing duties respecting the elderly, the disabled, and those in rural areas are retained, and new duties regarding the interests of low-income consumers and the chronically sick have been introduced. ${ }^{74}$ In place of the somewhat inconsistent and opaque duties applying to each regulator under the original utility statues, the Act gives the new energy regulator a single new overriding duty. ${ }^{75}$ This duty will require it

to protect the interests of consumers, wherever possible and appropriate, through promoting effective competition. The interests of consumers should be interpreted to

67. See Department of Trade And Indus., A FAir DeAl For Consumers: The Response TO CONSULTATION 1998.

68. See Department of Trade And Indus., A FAir DeAl For Consumers: Modernising THE FRAMEWORK FOR UTILITY REgulation, 1998, Cmnd. 3898; the final proposals are in the DEPARTMENT OF TRADE AND INDUS., supra note 67.

69. DePARTMENT OF TRADE AND INDUS., supra note 68, ๆा 2.13-18, 5.4; DePARTMENT OF TRADE AND INDUS., supra note 67, ๆ $10-14$, at 57-62.

70. Department of THE EnV'T, TRAnsport and The Regions, UK Climate Change PROGRAMME, 1998, ๆ 66.

71. See Utilities Act, 2000, $\S \S 70,99$ (U.K.).

72. See Secretary of StATE fOr Trade And Industry, PARl. Deb., H.C. (5th ser.) cols. 55560 (2000).

73. See Utilities Act, 2000, $\S 70,99$ (U.K.).

74. See Utilities Act, 2000, § 9 (U.K.) (adding a new $\S 4($ AA)(3) to the Gas Act, 1986 (U.K.)), $\$ 13$ (adding a new $\S 3(\mathrm{~A})(3)$ to the Electricity Act, 1989 (U.K.)); DEPARTMENT OF TRADE AND INDUS., supra note 67 , II 13 ;

75. See Utilities Act, 2000, $\S 9$ (adding a new § 4(AA)(1) to the Gas Act, 1986 (U.K.), § 13 (adding a new $\S 3(A)(1)$ to the Electricity Act, 1989 (U.K.)). 
include prices and conditions of supply, continuity and availability of supply, quality of supply, and, where relevant, the range of services offered. In defining the interests of consumers, due weight should be given to their long-term and medium-term interests as well as to their immediate or short-term interests.

Although the importance of competition is explicitly addressed, the other matters mentioned clearly permit the energy regulator to take social considerations into account; indeed, the duty to comply with social and environmental guidance from ministers requires this. The reforms also envisage the creation of a more effective and independent form of consumer representation in relation to the utilities. Based on past experience, this will provide a channel for the continual monitoring of industry performance in relation to social concerns. ${ }^{77}$

In addition to the legislative reform, the Government also asked the energy regulators to draw up an action plan to ensure that disadvantaged customers benefit from the advantages of opening up the gas and electricity markets to competition. $^{78}$ The plan confirmed that measures had already been taken to protect such consumers, and that in the case of gas, research had shown that the proportion of customers changing to new suppliers was, in general, evenly distributed across all social groups. As mentioned above, however, the National Audit Office and others have expressed some concern that disadvantaged consumers have not benefited as much as others. ${ }^{79}$ A remaining issue was the higher charges paid by prepayment meter customers. Some steps had been taken to reduce these prepayment charges, and other alterations in the charging system emerged as possibilities to benefit such customers. ${ }^{80}$ The first version of the action plan, however, did little more than to restate the existing arrangements to protect vulnerable consumers in the liberalized markets described above. After criticism, a revised draft was considerably more far-reaching, including proposals both for more detailed research and the strengthening of the obligations imposed on energy supply companies. For example, companies would be required to accept more frequent cash payments and to accept improved codes of practice on pre-payment meters, and to charge a binding maximum fee for the permitted surcharge payable by customers for the use of such meters. These reforms have now been implemented. ${ }^{81}$

The move toward legally enforceable public service requirements has culminated in the plan announced in the summer of 1999 for reform of the Post Office implemented by the Postal Services Act $2000 .^{82}$ A new regulatory com-

76. See DEPARTMENT OF TRADE AND INDUS., supra note 67, ๆ 16.

77. Id. ๆ 17-21; see also Utilities Act, 2000, § 2 (U.K.) \& sched. 2.

78. See OfFice of Electricity Regulation \& OfFice of Gas Supply, The Social DIMENSION: ACTION PLAN 2 (1998).

79. See NATIONAL AUdit OFFICE, supra note 44.

80. See OfFice of Gas And Electricity Markets, Social Action Plan: A Framework DOCUMENT 21 (Oct. 1999) (visited Nov. 21, 2000) <http://www.ofgem.gov.uk/docs/social.pdf>.

81. See id.; OfFICE OF GAS AND ElECTRICITY MARKETS, SOCIAL ACTION Plan (Mar. 2000) (visited Nov. 21, 2000) <http://www.ofgem.gov.uk/docs/sapmarch.pdf>; OFFICE OF GAS AND ELECTRICITY MARKETS, SOCIAL ACTION PLAN: ENHANCING SOCIAL OBLIGATIONS: A PROPOSALS DOCUMENT (visited Nov. 21, 2000) (Jan. 2000) <http://www.ofgem.gov.uk/docs/socjan.pdf>.

82. See DEPARTMENT OF TRADE AND INDUS., supra note 21. 
mission has been created, and its primary duty is to maintain universal postal delivery service throughout the United Kingdom at a uniform tariff. This duty is enshrined and defined in law for the first time. ${ }^{83}$ Minimum criteria will also be set for access to services, such as the protection of rural post offices, and progress toward those goals will be monitored by the new regulator. ${ }^{84}$ Even before the passage of the Postal Services Act, the universal service obligation was initially set out in regulations implementing the European Community Postal Services Directive. ${ }^{85}$ As this example suggests, the long tradition of public service law in other European Community countries, such as France, is beginning to have a profound effect on the United Kingdom through E.C. law, and I shall now describe the French tradition before dealing with E.C. law in more detail.

\section{V \\ PUBLIC SERVICE IN FRANCE}

So far, I have described the domestic British influences that have resulted in the development of a new public service law in relation to utility services. These influences have included the institution of regulators independent from government and private enterprise, the failure to limit the statutory duties of the regulators to economic matters, and a more sympathetic attitude from the new Labour Government to social regulation in general. In addition, other Member States in the European Union, most notably France, have a tradition of protecting public service that is radically different from that of the United Kingdom. In the past this tradition had minimal effect on the United Kingdom, where political rather than legal protections were seen as the most appropriate way of ensuring that public service goals were protected. However, the Continental model has now begun to have an important influence due to the United Kingdom's membership in the European Union and the effect of E.C. law. It is thus essential to examine the protection of public service in other Member States, and France provides by far the most developed example. ${ }^{86}$

In France, the concept of public service has its roots in the Constitution. The Preamble to the 1946 Constitution includes a provision to the effect that "[a]ll property and enterprises of which the running has, or acquires, the character of a national public service or a de facto monopoly are to become public property." ${ }^{\prime 7}$ There has been some doubt about the meaning of this provision, and it has been interpreted broadly by the Conseil Constitutionnel. ${ }^{88}$ Notably, it

\footnotetext{
83. See Postal Services Act, 2000, §§ 1-5 (U.K.).

84. See DEPARTMENT OF TRADE AND INDUS., supra note 21, chs. 4, 7.

85. See Postal Services Regulations, 1999, S.I. 2107.

86. For a more general discussion of public service in the European Union, see PUBLIC SERVICES AND CITIZENSHIP IN EUROPEAN UNION LAW, supra note 3.

87. LA CONSTITUTION DU 4 OCTOBRE 1958, preamble (Preamble to Constitution, 1946) (amended 1992) (Fr.).

88. Notably in the Privatizations decision, see Conseil constitutionnel (Cons. const.), June 25-26, 1986, C.C. 207, 1986, No. 86-207 DC (visited Nov. 16, 2000) <http://www.conseilconstitutionnel.fr/decision/1986/86207dc.htm>.
} 
does not apply to local public services such as water, which has for some time largely been supplied by private companies operating under concession.

The concept of service public is much more fully developed in French administrative law than in British law." It can be summarized as follows: "In French public law, public service is an activity in the general interest, provided by a public or private actor and subject to a special legal regime requiring equality of treatment, adaptation to changing needs and security of supply, etc." 90 The principle of public service has been implemented in two ways: through public ownership and through the granting of public service concessions for private concerns. Indeed, concessions also have been used to set out a framework for the operation of public enterprises. In much of the rhetoric concerning public service, an intrinsic interdependence of three elements has been assumed: (1) public service defined in law; (2) public ownership; and (3) a public monopoly to enable the distinctive tasks of public service to be achieved. It is important to point out, however, that in legal terms at least, service public is not synonymous with public ownership, or even with the granting of monopoly rights. Service public may also be a means of incorporating certain social principles into the operation of private enterprises in the market place; this is likely to be its most important role in the future. ${ }^{91}$ It is also important to note that service public is essentially non-economic and distributive in nature: "It is the essence of service public, as a means of consolidation of the social contract and of social solidarity, that it contributes to some types of redistribution and of transfers between social groups." ${ }^{2}$

What are the actual requirements of a regime of service public? The basic requirement is that of equality, ensuring equal access to services and equal treatment of consumers unless there is good reason not to do so. This may result in a rule prohibiting arbitrary pricing distinctions or restrictive access conditions. Other principles of equality include continuity of public service, which has most often concerned the extent of a right to strike on the part of public sector workers. Equality may also require security of supply, a key issue in energy liberalization. Service public also requires political neutrality in the provision of services. Echoing concerns in Anglo-Saxon utilities regulation, the participation of consumers in the administration, or at least in the regulation of services, as well as transparency of administration also have become part of the require-

89. For a comprehensive overview, see PUBLIC SERVICES AND CITIZENSHIP IN EUROPEAN UNION LAW, supra note 3 . There is a vast and fast-growing French literature on the subject.

90. Marc Debène \& Olivier Raymundie, Sur Le Service Universel: Renouveau Du Service Public ou Nouvelle Mystification? 52:3 AJDA 183, 186 (1996). My translation is a loose one in view of the difficulty in conveying the flavour of the concept in English.

91. See CONSEIL D'ETAT, supra note 3, at 26-29. The point has been re-emphasised in the decision of the Conseil constitutionnel concerning the partial privatization of France Télécom. See Cons. Const., July 23, 1996, R.J.C. 1996, No. 96-380DC (visited Nov. 16, 2000) <http: www.conseilconstitutionnel.fr/decision/1996/96380dc.htm>. The issue has also been addressed in the recent and influential report to the Prime Minister by an official Commission on Public Service. See DENOIX DE SAINT MARC, supra note 3, at 17, 43, 77-78.

92. See CONSEIL D'ETAT, supra note 3, at 53 (author's translation). 
ments of a service public regime..$^{93}$ These basic requirements are central principles of French administrative law but are implemented and supplemented by extensive statutory and regulatory requirements. ${ }^{94}$ Though it is outside the scope of this article, the concept of service public has also played a major role in the regulation of broadcasting in France, particularly its attempts to defend public service broadcasting within the European Union and in relation to the GATT cultural exception. ${ }^{95}$

VI

\section{CONFLICTS WITHIN THE EUROPEAN UNION OVER THE NEW CONCEPT OF PUBLIC SERVICE}

Because of the differing degrees of legal protection of public services in the Member States of the European Union, there have been fierce conflicts within the European Union as to the degree to which public utility markets should be opened to competition. ${ }^{96}$ The U.K. model of liberalization is often presented as a threat to the values of public service, while France's model is seen in the Anglo-Saxon world as protecting inefficient state enterprises through a system of special privileges.

In fact, both models find support in E.C. law. Thus, Articles 81 and 82 of the Treaty establishing the European Community ${ }^{97}$ set out the basic principles of competition law that are made applicable to public enterprises by Article 86(1). ${ }^{98}$ The rapid process of liberalizing the telecommunications industry, the first example of utility liberalization, took place through a model of utilities detached from direct government control and working in competitive markets. ${ }^{99}$ Universal service remains a value to be protected by specific interventions within the competitive marketplace, rather than by any overall regime of public service. ${ }^{100}$ Similar assumptions can be found in the arrangements adopted for the liberalization of civil aviation and, subject to greater qualification, electricity

93. All these principles are analysed in detail in $i d$.

94. For an illustration of the application of public service principles to the French postal service, see Case T-106/95, Fédération Française des Sociétés d'Assurances (FFSA) v. Commission of the European Communities, 1997 E.C.R. II-229.

95. See Philip Schlesinger, From Cultural Defense to Political Culture: Media, Politics and Collective Identity in the European Union, 19 MEDIA, CULTURE \& SOC'Y 369 (1997).

96. See, e.g., Services of General Interest in Europe, COM(96)443 final.

97. Formerly articles 85 and 86; TREATY ESTABLISHING THE EUROPEAN COMMUNITY, Feb. 7 , 1992, O.J. (C 224) 1 (1992), [1992] 1 C.M.L.R. 573 (1992) [hereinafter E.C. TREATY].

98. Formerly article 90(1), E.C. TREATY.

99. For a good summary of the early stages of this process, see A. Hunt, Regulation of Telecommunications: The Developing EU Regulatory Framework and its Impact on the United Kingdom, 3 EUROPEAN PUB. LAW 93 (1997).

100. See, e.g., Developing Universal Service For Telecommunications in a Competitive Environment, COM(93)159 final; European Parliament and Council Directive 98/10/EC on the Application of Open Network Provision to Voice Telephony and on Universal Service For Telecommunications in a Competitive Environment, 1998 O.J. (L 101) 1.4. For an outstanding critical discussion, see Wolf Sauter, Universal Service Obligations and the Emergence of Citizens' Rights in European Telecommunications Liberalization, in PUBLIC SERVICES AND CITIZENSHIP IN EUROPEAN UNION LAW, supra note 3, at 117. 
and gas. With regard to the structures of enterprises to be adopted in the future, Article 295 of the Treaty ${ }^{101}$ apparently preserves neutrality between different forms of property ownership-in other words, whether an enterprise is publicly or privately owned. However, there is no doubt that state aid policies have been a major contributing factor to privatization throughout the European Union, as they require that public enterprises be treated no differently from enterprises that are privately owned..$^{102}$ Thus, what is the point of keeping enterprises public if they cannot be subject to a different regime? While this point must be qualified for the utilities, the notion in other cases has been important in shaping policy on privatization. Moreover, jurisprudence from the European Court of Justice has restricted or ended certain special privileges of public utilities. For example, one decision limited the ability of British Telecom to act anti-competitively even before it became privatized. ${ }^{103}$ The Commission's support for this model of utilities operating in a competitive marketplace with a residual role for universal service has led to sustained criticism from Continental Member States. These states claim that the Commission is "a liberalisation machine, ultra-liberal and dogmatic." ${ }^{104}$ In other words, it is alleged that the Commission has ignored the broader conception of public service.

On the other hand, the French-based model of public service has also had an important place within E.C. law. Thus, Article 86(1), applying the competition principles to public enterprises, is immediately qualified by the following subarticle that provides a limited defense against their application in the case of "services of general economic interest," in order that their application does not obstruct the performance of the tasks entrusted to bodies providing such services. ${ }^{105}$ The jurisprudence of the European Court of Justice also indicates an acceptance of the legitimate role of public service. For example, in the wellknown case of Corbeau, the Court accepted that the normal principles of E.C. competition law could be limited to permit the conferring of exclusive rights on a state monopoly to the extent necessary to preserve a universal service through cross-subsidy. ${ }^{106}$ Similarly, in the Almelo decision, the Court specified that the competition rules could be modified if necessary to ensure a continued supply of electricity on demand to all types of consumers on the basis of uniform tariffs and non-discriminatory conditions throughout the areas covered by their

101. Formerly Article 222.

102. See Commission of the European Communities, Fourteenth Report on Competition Policy (1985), point 198; Case C234/84, Belgium v. Commission of European Communities, 1986 E.C.R. 2263, [1988] 2 C.M.L.R. 331, ๆ 13 (1986). The largest and most controversial example has been that of state aid to Crédit Lyonnais. See Commission Decision 98/490/EC of 20 May 1998 Concerning Aid Granted By France to the Crédit Lyonnais Group, 1998 O.J. (L 221) 28.

103. See Case C41/83, Italy v. Commission of European Communities, 1985 E.C.R. 873, [1985] 2 C.M.L.R. 368 (1985).

104. See Karel Van Miert, L'Europe, Vecteur De La Libéralisation, Speech, Paris, France (Oct. 21, 1996).

105. Formerly article 90(1), E.C. TREATY.

106. See Case C-320/91, Regie des Postes v. Corbeau, 1993 E.C.R. I-2533, [1993] 4 C.M.L.R. 621 (1993). 
authorizations. $^{107}$ In early 1997, the Court of First Instance rejected a challenge to the way in which the French postal service had been compensated for its public service obligations, confirming the discretion given to Member States in arranging such compensation. Furthermore, the court found that support permitted under Article 86(2) would not constitute unlawful state aid. ${ }^{108}$

During the period preceding the Amsterdam Inter-Governmental Conference, which determined important reforms to the treaties on which the European Union is based, the European Centre of Enterprises with Public Participation and other pressure groups campaigning on behalf of public enterprises led a vociferous campaign in favor of the amendment of the treaty in a way that would have seriously weakened the application of Article 86(1). The proposed amendment would permit the Member States to decide which activities would form part of "services of general economic interest." The French and Belgian governments also proposed treaty amendments to guarantee universal rights of access to such services. ${ }^{109}$ The European Parliament passed a resolution stating that the "fundamental principles of public service, i.e. accessibility, universality, equality, continuity, quality, transparency and participation in the context of the single market and respecting the principle of subsidiarity, should be incorporated in the Treaty." 110 The Commission itself made much more limited proposals for the addition of "a contribution to the promotion of services of general interest" to the list of Community activities in the treaty. ${ }^{111}$ There was considerable political division within the Conference between the Member States favoring such an amendment and those, including the United Kingdom, who believed that current treaty provisions ensured an adequate balance between competition policy and the needs of a public service. What was eventually agreed upon was a French-inspired amendment to add a new Article 16 to the treaty as follows:

Without prejudice to Articles 77, 90 and 92, and given the place occupied by services of general economic interest in the shared values of the Union as well as their role in promoting social and territorial cohesion, the Community and the Member States, each within their respective powers and within the scope of application of this Treaty, shall take care that such services operate on the basis of principles and conditions which enable them to fulfil their missions. ${ }^{112}$

107. See Case C-393/92, Almelo v. Energiebedrijf Ijsselmij NV, 1994 E.C.R. I-1477; see also Case C157/94, Commission of European Communities v. Netherlands, 1997 E.C.R. I-5699.

108. See Case T-106/95, Fédération Française des Sociétés d'Assurances (FFSA) v. Commission of the European Communities, 1997 E.C.R. II-229.

109. See, e.g., Centre Européen À Participation Publique, Europe, Concurrence et SERVICE PUBLIC (1995); European Centre of Enterprises with Public Participation (CEEP), Europe, Competition and Public Service (Apr. 17, 1996) (press release).

110. Resolution of the European Parliament on the Intergovernmental Conference, 1996 O.J. (C 96) 77.

111. Communication from the Commission-Services of General Interest in Europe, COM(96)443 final.

112. Treaty of Amsterdam, Amending the Treaty on EuropeAn UniON, Oct. 2, 1997, O.J. (C 340) 16 (1997). 
A Declaration stated that these provisions should be implemented "with full respect for the jurisprudence of the Court of Justice, inter alia as regards the principles of equality of treatment, quality and continuity of such services." ${ }^{\prime 13}$ Other amendments aim to protect public service broadcasting. ${ }^{114}$ It has yet to be seen whether these amendments have more than symbolic importance, but even if their practical effect is limited, they represent a fuller recognition of the role of public service in the basic principles of European law. Indeed, it has been argued strongly that they go much further than the merely symbolic, and provide a new concept of public service to promote cohesion and shared values, which must be respected by Member States. ${ }^{115}$

The more important practical development has been the emergence of more detailed principles in particular areas of liberalization. As mentioned above, this trend has reached its most advanced stage in the telecommunications industry. ${ }^{116}$ Here, the dominant Continental model was that of a monopoly public enterprise which would be expected to deliver public service objectives; in practice, however, even legal requirements of public service often were not fulfilled. ${ }^{117}$ This model has been succeeded by full telecommunications liberalization as a result of community action. Built into this liberalization have been requirements of universal service that go considerably farther than earlier requirements in guaranteeing a basic minimum standard and other service standards which may develop beyond basic telephony. As one commentator has put it, "[t]he paradoxical result may well turn out to be that true universal service will for the first time be available throughout the European Union after liberalisation has been completed."118

The European dimension has also had an important influence on the U.K. telecommunications universal service measures discussed above. The impact of E.U. policies in the United Kingdom is becoming apparent in the area of postal services, where, as part of an internal market, Community law requires a defined universal service obligation, which sets criteria for defining the monopoly services necessary for maintaining universal service, and maintains prices that are affordable, geared to costs, and non-discriminatory. It also requires the setting and publication of service standards and the establishment of a national regulatory authority separate from the public postal operator. ${ }^{119}$ These policies

113. Id. art. 2(8), Declaration on Article 7d of the Treaty Establishing the European Community. The numbering quoted refers to the old numbers of the Treaty Articles; the new equivalents to arts. 77, 90 , and 92 are arts. 73,86 , and 87.

114. See Treaty of Amsterdam, Protocol on the System of Public Service Broadcasting in the Member States, 1997 O.J. (C 340) 109.

115. Malcolm Ross, Article 16 E.C. and Services of General Interest: From Derogation to Obligation?, 25 EUR. L. REV. 22 (2000).

116. See Sauter, supra note 100 , at 122-23, 133.

117. See id.

118. Id. at 142; see also Universal Service For Telecommunications in the Perspective of a Fully Liberalised Environment, COM(96)73.

119. See Directive 97/67/EC on Common Rules For the Development of the Internal Market of Community Postal Services and the Improvement of Quality of Service, 1998 O.J. (L 15) 14. 
were indeed introduced into the United Kingdom as a result of E.C. obligations before the implementation of fuller postal reforms.

The relationship between the open-ended legal concept of public service and the more limited concept of universal service as an exception to a presumption in favor of competitive markets remains the subject of considerable debate, especially in France. The more limited concept of universal service has prevailed in the European Union. ${ }^{120}$ It is possible, however, that the practical differences between the two are relatively small. Moreover, particularly in the field of telecommunications, Continental concerns preserving the public service tradition have influenced the evolution of E.C. law. These concerns, in turn, have provided reasons for moderating, on social grounds, the free play of market competition in the operation of the U.K. utilities. Nor has the traffic been only one way, for there have been examples of the Anglo-Saxon model influencing countries with a strong public service tradition. Apart from the extensive adoption of independent regulatory commissions, ${ }^{121}$ more specific examples include France's adoption of a Charter of Public Services in 1992 in an attempt to spell out the requirements of public service in greater detail. This charter is analogous to the U.K. practice of using service standards. ${ }^{122}$ Italy also adopted a law on the delivery of public services in 1994, which sets out fundamental principles of public service based on the French model. Those principles, however, will be implemented by service standards similar to British practice. ${ }^{123}$

\section{VII}

\section{CONCLUSION}

What has occurred in the United Kingdom is thus a move toward the development of a body of legal doctrine closer to the concept of public service enshrined in other European legal systems. I do not wish to argue that this is a direct result of privatization itself. Rather, it has been due largely to the creation of regulators independent of government and enterprise, thus making some legal framework to structure relations inevitable. ${ }^{124}$

It is, of course, not impossible that such a regime could exist while retaining public ownership. Indeed, in the United Kingdom, postal services, and in Scotland, water and sewerage, are subject to independent regulation while remain-

120. See, e.g., P. Barbet and A. Gonzalez, La Notion de Service Universel dans les Télécommunications, LXIII REVUE INTERNATIONALE DE DROIT ECONOMIQUE 59 (1999); John Bell, The Concept of Public Service Under Threat? An Illustration from Energy Law, 5 EUROPEAN PUB. L. 189 (1999).

121. See Giandomenico Majone, The Rise of Statutory Regulation in Europe, in REGULATING EUROPE 47 (Giandomenico Majone ed., 1996).

122. See M. Bechtel et al., Chronique de l'Administration, 62 REVUE FranÇAISE

D’ADMinistration Publique 335, 337 (1992).

123. See Direttiva del Presidente del Consiglio de Ministri, Jan. 27, 1994, Gazzetta Ufficiale della Republica Italiana, n. 43 (Feb. 22, 1994).

124. This is the major difference from New Zealand, where such regulatory arrangements were not established. 
ing under public ownership. ${ }^{125}$ Indeed, it may be that publicly owned enterprise is necessary to establish the infrastructure for universal service, though not necessarily for its operation.

The second major influence has come about through Britain's membership in the European Union. Again, while pressing for the opening of utility markets to competition (though not always requiring privatization), the European Union has fostered the separation of regulation from operation of the enterprise, thereby making a legal framework necessary. Continental public service concerns have infiltrated this liberalization, requiring clearer legal definitions of limitations on the operation of the free market undertaken on distributive grounds.

In the United Kingdom, the new public service law is not mainly administered by the courts, but by the regulatory bodies themselves. This has advantages such as the avoidance of damaging litigation while retaining the courts as adjudicators in cases of real difficulty. It is clear that we are now seeing the beginning of the replacement of ineffective political controls over public enterprise by legal principles that include elements of social solidarity and rights of access to essential services. ${ }^{126}$ Privatization in the United Kingdom has given birth to some unexpected offspring.

125. The example of the Post Office is discussed in detail supra notes $74-85$ and accompanying text; see DEPARTMENT OF TRADE AND INDUS., supra note 21. For the new arrangements for water and sewerage services in Scotland, see the Water Industry Act, 1999, §§ 12-13, sched. 2.

126. This argument is made at greater length in Tony Prosser, Theorising Utility Regulation, 62 MODERN L. REV. 196 (1999). 